\title{
Farmers' Understandings of Weeds and Herbicide Usage as Environmental Influences on Agricultural Sustainability
}

\author{
David Kings \\ The Abbey, Warwick Road, Southam, Warwickshire, UK \\ Email: davidkings@fdkings725.freeserve.co.uk
}

Received 22 May 2014; revised 18 June 2014; accepted 12 July 2014

Copyright (C) 2014 by author and Scientific Research Publishing Inc.

This work is licensed under the Creative Commons Attribution International License (CC BY).

http://creativecommons.org/licenses/by/4.0/

(c) (i) Open Access

\section{Abstract}

Little comparative research has specifically used farmers' understandings of agricultural weeds and herbicides usage as important indicators of their environmental decision making and behaviours. This paper proposes that "organic' farmers", already attuned to environmental ideas, may be more likely to have favourable understandings and behaviours towards agricultural weeds as an integral part of environmentally sustainable agricultural farming systems than "conventional" farmers. Using a behavioural approach, the ways in which farmers' (situated in central-southern England) understandings influence their environmental behaviours were examined. Most "conventional" farmers' fields were kept relatively weed-free through herbicide usage. This contrasted with "organic" farmers having less concern about removal of weeds (with their associated invertebrates and seeds) which they understood contributes significantly towards biodiversity and agricultural sustainability. A remarkably high 92 per cent of "organic" farmers were critical of "conventional" farmers' using herbicides and pesticides, asserting that lack of pesticide and herbicide usage as core reasons for their sustainability. This contrasted with most "conventional" respondents who claim they used as few chemicals as practicable to minimise environmental damage to soil and water, while maintaining adequate crop levels. Nevertheless, such environmental understandings and behaviours may not always be indicative of any differences that may be found between those farmers commonly classified as "organic" and "conventional" in the UK as a whole.

\section{Keywords}

Understandings, Behavioural Approach, Agricultural Weeds, Organic Agriculture, Biodiversity, Agricultural Sustainability 


\section{Introduction}

This paper adopts a behavioural approach to examine the understandings and behaviours of those farmers commonly known as "organic" and "conventional” in relation to agricultural weeds, herbicide and pesticide usage, biodiversity and other selected environmental influences on agricultural sustainability. Reference [1] defined weeds as: “... plants that impact adversely on economic, aesthetic or environmental aspects of any system”. In practice, however, any vegetation that comes up in a field that the grower did not plant is often called a weed [2]. Weeds are successful and unusually competitive organisms which exhibit the ability to reproduce when young under a broad range of conditions and make an important contribution to biodiversity. Within the context of this research, biodiversity is defined as the variability of all living organisms on a respondent's farm, including species diversity, diversity within species and genetic diversity. A range of studies have argued that organic agricultural methods generally increase biodiversity [3]. Importantly, a larger and more diverse weed seed-bank can contribute significantly to biodiversity [4]. Indeed, [5] claim that farm weeds have a "crucial” role in sustainable agriculture. Sustainability, defined in the Brundtland Report as: "development that meets the needs of the present without compromising the ability of future generations to meet their own needs" [6], is a multi-faceted concept having agronomic, ecological, economic, social and ethical components [7], but often means different things to different people [8]-[11]. There is, however, no absolute measure of sustainability available [12] and, according to [13], the very idea of what sustainability means, in terms of on-farm practices, is not entirely self-evident. Recent researchers have done little to engage critically with the concept of environmental sustainability. This may be because the socially and politically constructed concept is slippery and broad-ranging [14]; but, according to [15], this enables sustainability's fluid, constructed nature to be used more broadly and creatively, as undertaken in this paper.

Some commentators claim that conventional farming systems in the UK have become environmentally unsustainable [16]-[19]. In contrast, organic farming is often seen as a holistic production management system that promotes and enhances agro-ecosystem health, including biodiversity, biological cycles and soil biological activity. It also emphasises the use of management practices, in preference to the use of off-farm inputs, and recognises that regional conditions require locally-adapted systems [20]. In March 2008, [21] endorsed the following definition:

"Organic agriculture is a production system that sustains the health of soils, ecosystems and people. It relies on ecological processes, biodiversity and cycles adapted to local conditions, rather than the use of inputs with adverse effects. Organic agriculture combines tradition, innovation and science to benefit the shared environment and promote fair relationships and good quality of life for all involved”.

There are, however, various organic farming practices, each with its divergent environmental views and value assumptions involving a variety of alternative methods of agricultural production which evolve as new scientific research becomes attainable. For example, [22]'s analysis identified two types of organic farmers, "pragmatic” and "committed”. In contrast, [23] sees organic farming as a family of styles that share some basic assumptions, rather than a single set of farming practices, while preserving the underlying philosophical perspective of working with, not dominating, natural systems and having respect for the natural environment [3] [24]-[26]. According to [27], many organic farmers emphasize ecological factors in their decision making processes. Recent research by [28] demonstrated that the majority of small organic farms (examined in central-southern England) were managed in an environmentally sustainable way by farmers whose environmental understandings and behaviours complied with the principles and values that are fundamental to organic farming. Such principles and standards employed in organic production constitute a radical break with the productivist paradigm [29]. However, according to [30], concern about weed populations without the use of herbicides has limited the uptake of organic farming. Farmers rank weeds as the number one barrier to organic production [31]; with many organic farmers citing weed management as their principle research priority [32]. Herbicides contribute significantly to agricultural intensification and some negatively impact on non-target organisms [33]. Reference [34] found that arable organic fields have more species-rich, denser seedbanks than arable conventional fields. Agricultural weed seeds present an agronomic threat but, importantly, they are also a significant food resource for wildlife in winter [35]. Reference [36] found strong overall correlations between the number of weed species and the total species diversity, indicating that arable weeds are "key species", the loss of which leads to serious changes in biodiversity.

Some writers are concerned that organic farming systems are becoming "conventionalized” in their produc- 
tion, marketing and distribution methods [37]-[40]. Other commentators claim that commercial organic agriculture has failed to live up to the promise of a realistic alternative to conventional agriculture and a truly sustainable form of farming [41], while, hopefully, leaving smaller organic enterprises to grow a variety of marketable crops but resisting economic pressures exerted by large commercial operations [37] [42]. Importantly, other researchers suggest that organic farming systems have the potential to "develop in distinct ways in different national contexts" [26] [42] [43].

The Weed Science Society of America conducted an online survey of its members; the largest group of which reported working on research problems focusing predominately on herbicide efficacy and maintenance, funded mainly by private industry sources. Reference [44], however, suggested that it may be unwise to limit weed science to such narrowly-defined limits but should be seen as an integrating discipline. Reference [22] claims that the debate must move beyond its focus on the bifurcation between artisanal and conventionalised organic farms to enable capture of the full range of empirical heterogeneity. Although weeds offer a serious threat to organic crop production, relatively little attention has been paid to research on weed management in organic agriculture [45] and no comparative research specifically using farmers' "understandings" of agricultural weeds and herbicide usage as important indicators of their environmental decision making and behaviours. To satisfy this gap in the wider contemporary scholarly debate, using a novel approach, this paper aims to assess the environmental behaviours of "organic" and "conventional" farmers, in relation to agricultural weeds and herbicide usage as important indicators of their environmental understandings towards biodiversity and other selected environmental influences on agricultural sustainability. In order to achieve that aim, a geographically linked farm/ farmer behavioural study was carried out in central-southern England. This research proposes that "organic" farmers, already attuned to environmental ideas, are more likely to have favourable understandings and behaviours towards agricultural weeds, as an integral part of environmentally sustainable agricultural farming systems, than "conventional" farmers.

The rest of this paper is divided into six sections. The next section reviews some key dimensions of behavioural approaches. This is followed by details of the adopted "extensive" and "intensive" research methodologies used to examine and explain farmers' environmental understandings. Section four examines and gains insights into the understandings and behaviours of organic and conventional farmers regarding their awareness and understandings of three closely related agri-environment themes. The penultimate section uses on-farm intensive qualitative/interpretive interviews to ascertain if the respondents' understandings and behaviours, in relation to their productive farm parts, support the findings revealed by the earlier telephone "extensive" interviews. A concluding section completes the paper.

\section{Behavioural Approaches}

The classic behavioural approach refers to a broad range of studies that employ actor-oriented quantitative methodologies to understand decision-making [46]. Behavioural approaches allow for the recognition of farmers as independent managers who often make environmental decisions about their farms independent from the state or other "official" environmental managers [47]. Although sometimes criticised for their relative neglect of "spatial science" and "partial" treatment of people [48], behavioural perspectives have been used widely in agricultural studies [28] [46] [47] [49]-[55] and applied to the analysis and understanding of farmers' environmental behaviours. Farmers make their environmental decisions as they understand it, not as it is, but the action resulting from their decision ... is played out in a real environment [56]. According to [52], such methodologies can be standardised and repeatable, thereby making them useful in monitoring change over time for EU policy-makers. These requirements have contributed to a recent increase in the application of "behavioural approaches" to investigate issues such as food security.

Behavioural approaches are suitable for examining the environmental understandings and behaviours of farmers in relation to agricultural weeds, herbicide and pesticide usage, biological diversity and other selected environmental influences on agricultural sustainability. However, behavioural approaches which use inflexible structured questionnaire methodologies and focus on individual decision makers out of their social or familial milieus may seem rudimentary in attempting to understand human behaviour [46]. To avoid such potential problems, the type of behavioural approach adopted by this study incorporates a balance of "quantitative" and "intensive qualitative/interpretive" work in its analysis and understanding of farmers' environmental behaviours. It is sometimes thought that "to know" is to understand, but "to understand" is a considerably more complex 
concept. To comprehend is probably the closest synonym to understand, although that falls far short of revealing the full meaning of understanding. Understanding can be considered a generalised meaning or insight. An insight is a basic sense of, or feeling for, relationships. A tested generalised insight is an understanding; it is a meaning or discernment that can be profitably applied to several or even many similar, but not necessarily identical, situations or processes. The most valuable insights are those confirmed by enough similar cases to be generalised into an understanding [57].

\section{Research Methodology}

The methodology used for examining farmers' understandings and behaviours towards agricultural weeds, herbicide and pesticide usage, biodiversity and other selected environmental influence on agricultural sustainability was structured in two stages:

Stage one consisted of hour-long "extensive" telephone interviews with twenty-five organic farmers and twenty-five conventional farmers. Central-southern England was selected as the geographical focus of the study because many organic farms, through a process of spatial rationalisation, have became concentrated in this location [58]. Recent distribution changes, however, indicate that the greatest concentration of organic farms is now in south-west England [59]. It is worth noting that structural change in agriculture is leading to fewer, larger and generally more intensive farms in central-southern England [60]; thereby suggesting a general reduction in biodiversity and agricultural sustainability, which smaller organic farms could partly ameliorate. The organic farmers were classified OF1 to OF25 and the conventional farmers CF1 to CF25 to assist data analysis. Organic farmers, selected from the official regional Soil Association and Organic Farmers and Growers membership lists, were interviewed first. Each respondent was asked to provide details of a neighbouring conventional farmer who they thought appropriate for interview. This method provided dependable geographically linked pairs of farmers during the investigation. Any concerns about providing a reliable national representative sample were unnecessary as it was anticipated that the sample study group may or may not be representative of farms and farmers in the UK as a whole. A questionnaire was designed for use in the "extensive" data gathering approach. These data were analysed both quantitatively, using summarising statistics, and qualitatively, in the form of farmers' quotations and illustrative farm cameos to emphasise the arguments being developed about their attitudes, understandings and behaviours in relation to agricultural weeds, herbicide and pesticide usage, biological diversity and other selected environmental dimensions of agricultural sustainability.

Stage two of the methodology consisted of 3 hour on-farm "intensive" qualitative/interpretive interviews, with a sub-sample (10) of five geographically linked pairs of organic and conventional farmers who, earlier in the investigation, had been part of the extensive telephone survey. The organic farmers were classified OF1 to OF5 and the conventional respondents CF1 to CF5 to facilitate data analysis. Importantly, the reference classifications assigned to the ten respondents are not always the same as those used in the telephone interviews. An illustrative sample of different ages, farm holdings of different sizes and systems was selected in preference to a representative sample. An interview guide was designed which prompted respondents to discuss their productive farm parts. The interviews were recorded using a Digital Audio Mini Disc-recorder with stereo microphone and transcribed for analysis soon after. In contrast to the extensive telephone survey, the data generated from stage two of the methodology were analysed using a textual approach using words and meanings. Any interesting or unusual quotations and paraphrases made by respondents were analysed in order to demonstrate similar understandings and differences. The interviews produced contextual findings relating to the respondents' environmental understandings and behaviours towards agricultural weeds as important indicators of agricultural sustainability in central-southern England.

\section{Investigating Farmers' Understandings and Behaviours}

In this section, the adopted "extensive" research methodology is used primarily to examine and gain insights into the understandings and behaviours of organic and conventional farmers regarding their awareness and understandings of three closely linked agri-environment themes in relation to agricultural weeds, herbicide and pesticide usage, biodiversity and agricultural sustainability.

\subsection{Organic Farming Systems}

Organic agriculture is often understood as an environmentally friendly way of farming. This attitude was typi- 
fied by a comment from OF2: “They [organic farmers] work with the natural environment; basically what they are doing is making the best of what is naturally there and working along with it". In more detail: "Yes, I think by avoiding herbicides and pesticides we are increasing the whole spectrum of insects and micro-organisms in the soil ...”(OF14). However, in contrast, conventional farmers' replies were generally not in support of those understandings and are typified by the following comment: "I think organic grass farmers cause more problems with nitrates, than I do, by ploughing clover [into their soil]” (CF13).

Respondents were asked what they know about the amount of fossil fuels used by some organic farmers in the mechanical weeding processes. Those methods of operation involve dragging tines, or hoes, across the soil surface to remove young weeds [61]. Almost all the organic respondents understood that organic arable farmers use a lot of fossil fuels, typified by answers such as: “... it’s true we do use a lot of fossil fuels in the weeding processes” (OF4). Most conventional farmers in the survey were not critical of organic farmers in relation to this issue. Typical comments include: “... but they don't have many options-they have to do that” (CF6). Weed management, however, can be improved by a range of ecological mechanisms, such as biological control and crop rotation, without the over-use of mechanical weeding processes [25] [62].

A stacked histogram is used to graphically display the diversity of farmers' understandings in relation to whether organic agriculture is environmentally sustainable (Figure 1).

Not surprisingly, considerably more organic than conventional farmers understood that organic agriculture is an environmentally sustainable form of agriculture. A further fifth of the organic respondents understood that it could be sustainable: "I think it could be [sustainable] if it's allowed to be managed properly" (OF18) with almost as many conventional farmers supporting those understandings with responses such as: "It depends on the quality of your land and how good the condition is to start with” (CF20). In contrast, almost a third of conventional farmers understood that organic production is environmentally unsustainable in comparison with only one organic farmer who agreed with that understanding.

Organic farmers were asked their reasons for their change to, or adoption of, an organic farming system which is shown in descending rank order (Table 1 ).

Table 1 shows that $48 \%$ of organic farmers say environmental concerns are their main reason for adoption of organic methods and also a further $20 \%$ consider they have always farmed organically. One 45 year old owner-occupier farmer claimed: "The toxicity of the chemicals used in my intensive agriculture made me feel quite poorly_nothing but 'wall to wall' arable prior to that date except for odd corners I couldn't crop”, thereby demonstrating his concerns about health problems associated with herbicide and pesticide usage in conventional farming (OF10). Another respondent farming 88 hectares, claimed that: "We have always been organic ... always followed organic principles even when we were conventional farmers”, thereby demonstrating an ecocentric tendency towards the farmed environment and agricultural sustainability (OF12). Of those twelve farmers who gave environmental reasons for changing to organic, three are unqualified, one has a certificate, two have a diploma, four a degree, one a higher degree and one a Doctorate which may suggest a link between higher education and environmental awareness and understandings. Research by [63] supports those findings.

In contrast, Table 2 provides a list of reasons provided by conventional farmers for their non-adoption of organic farming shown in descending rank order.

Four key findings emerge from Table 2: first, 28\% of conventional respondents said organic farming wouldn't suit their type of land; second, 24\% gave financial reasons for their non-adoption; third, 20\% gave technocentric reasons for their non-adoption; and fourth, only one conventional farmer said he would consider changing to organic. One 55 year-old owner-occupier said: “No-I don't think we have got good enough soil type on the farm" (CF24). Another conventional 56 year-old respondent, demonstrating his scepticism towards organic farming, cynically said: "No-because it's a limited market - there are only a certain number of people who can afford to pay over the odds for something that's allegedly organic" (CF8).

Several of the conventional farmers showed technocentric understandings in the above analysis; for example, believing that organic farming methods are restrictive and rule out modern science. According to [64], technocentrism is a mode of thought which recognises environmental problems but believes that society will always solve them through science and technology and achieve unlimited material growth (cornucopian). This contrasted with the more ecocentric understandings that most of the organic respondents demonstrated by their reluctance to use herbicides and pesticides. Ecocentricism can be defined as a mode of thought which regards humans as subject to ecological and system laws; essentially it is not human-centred (anthropocentric) but centred on the natural ecosystems, of which humans are just another component [64]. There is a strong sense of respect for nature in its own 


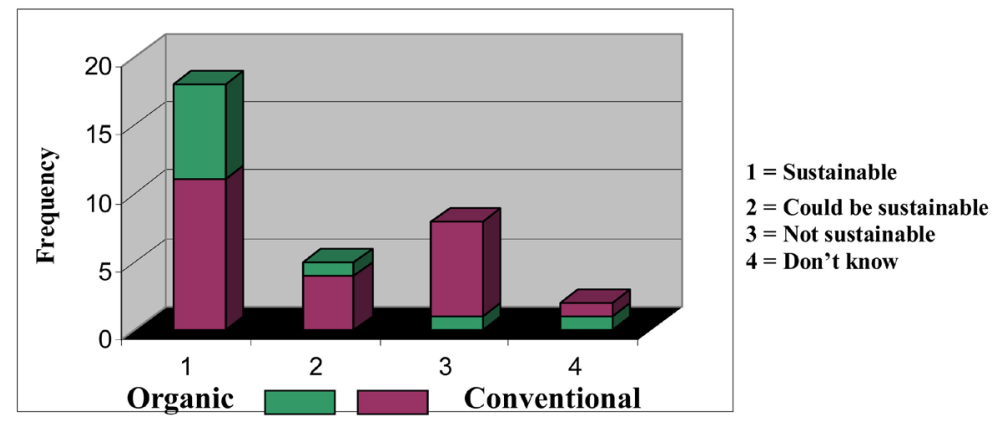

Figure 1. Frequency of farmers' opinions on sustainability of organic farming.

Table 1. Reasons for adoption of an organic farming system.

\begin{tabular}{ccc}
\hline Listed in rank order by reason for adoption & Frequency & \multicolumn{2}{c}{ Percentage } \\
\hline Environmental reasons including pesticide concerns & 12 & 48 \\
Considered they had always farmed organically & 5 & 20 \\
Financial reasons including customer requirements & 4 & 16 \\
Not in farming previously & 1 & 4 \\
Small scale - needed to go intensive or organic & 1 & 4 \\
Had farmed organically on a previous farm & 1 & 4 \\
The challenge & $\mathbf{2 5}$ & $\mathbf{1 0 0}$ \\
Total & & \\
\hline
\end{tabular}

Respondents' range of answers were carefully placed into the above categories.

Table 2. Reasons for non-adoption of organic farming.

Listed in rank order by reason for non-adoption

Wouldn't suit the ground/way we farm

Financial reasons - producer and buyer

Cramping, restrictive and ruling out modern science

Don't think it always works

Would consider changing to organic

No, but no reason given

My farm is organic for all intents and purposes

Total

\begin{tabular}{cc} 
Frequency & Percentage \\
7 & 28 \\
6 & 24 \\
5 & 20 \\
4 & 16 \\
1 & 4 \\
1 & 4 \\
1 & 4 \\
$\mathbf{2 5}$ & $\mathbf{1 0 0}$ \\
\hline
\end{tabular}

Respondents range of answers have been carefully placed into the above categories.

right. A comment from (OF10) typified such respect: “... if my footprint has been light on the world, and not abusing, then I will be happy”. It would be unwise, however, to believe that farmers have exclusively technocentric or ecocentric understandings. The boundaries are likely to be blurred with every farmer favouring elements of each mode depending on the institutional setting and issues at hand. For example, conventional farmers may be just as likely as organic farmers to be aware of the dangers of applying high levels of herbicides and pesticides, but understand that their job requires it. The very nature and constraints of their farming type may influence them into decisions paths from which they may have difficulty in avoiding.

\subsection{Conventional Agriculture}

Both survey groups were asked if they understood that conventional agriculture was having negative environmental impacts. The frequency of farmers' responses have been categorised under the five headings detailed in Figure 2.

The figure shows that fewer conventional than organic farmers understand that conventional agriculture is 


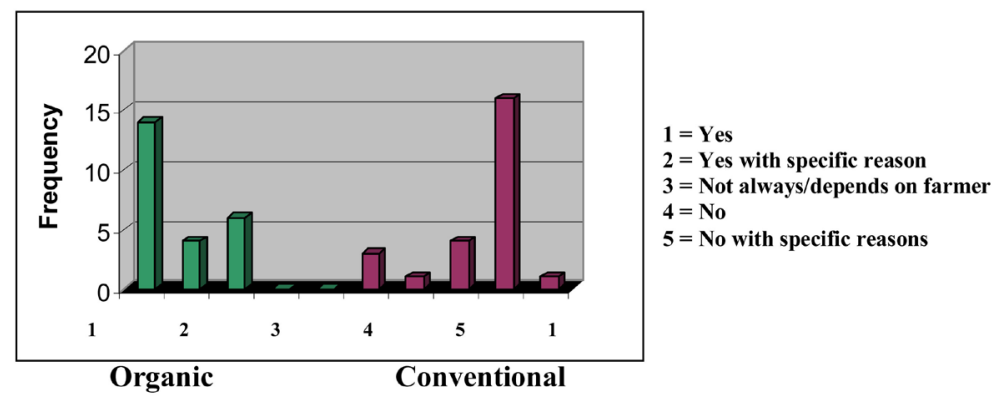

Figure 2. Frequency of farmers' response to environmental impacts of conventional farming

having negative environmental impacts. Fourteen (56\%) organic farmers understood that conventional agriculture is harmful to the environment in contrast to three (12\%) conventional farmers. Another four (16\%) organic farmers said yes, but qualified their answer with specific reasons for their environmental concern such as: "High levels of nitrate and pesticides on crops". Another organic farmer with a post graduate degree replied: "not always, as often as not its not a very good thing-like anything at its worst it depends on the farmer and his attitude ...” (OF10). Only one organic farmer said conventional farming is not having any negative impacts compared with 16 (64\%) of conventional farmers who agreed with that statement.

Organic farmers were more critical than conventional respondents of the herbicides and pesticides used in conventional agriculture causing damage to water quality. Organic farmers' responses to this issue were relatively consistent with $92 \%$ saying conventional agriculture is harmful to water quality, epitomised by quotes such as: "I definitely think it [herbicides and pesticides used in conventional agriculture] has a negative effect on water quality", and the remaining $8 \%$ saying they were not sure if it is harmful. At the other end of the spectrum, only $40 \%$ of conventional farmers understood that conventional agriculture is harmful to water quality. Sometimes they qualified their answer by typically saying: "It [conventional agriculture] affects it—but a very small portion — only one part per billion". Twenty per cent understood that conventional agriculture didn't affect water quality, with quotes like: "pesticides—it doesn't make any difference”. Thirty six per cent qualified their answer with replies such as: "I think it [conventional agriculture] can have, but it depends on what the situation is in". One conventional farmer, with a National Certificate in Agriculture, endeavoured to explain his distinction between intensive farming methods and conventional farming, claimed: “... organic farmers sometimes have to farm more intensively [than conventional farmers] as they have to be 100 per cent more switched on” (CF23). However, the way in which the word "intensively" is used in his observation seems to imply that organic farmers require an intensity of attention towards organic means of production as they do not use herbicides and pesticides.

Analysis showed that the organic farmers in the survey are very critical of herbicide and pesticide use: "If you keep putting on too much fertiliser and sprays on the land it does affect everything - there is no life in the land" (OF12). This contrasted with conventional farmers, who understood that they need to use herbicides and pesticides to produce their crops but are generally aware of the dangers of over-use of such chemicals. Typical organic farmers' responses included: "They [conventional farmers] are dependent on pesticides for their production" (OF1). "Conventional farming is lazy farming, it’s farming out of a can, whereas with organic farming, you have to farm with your head" (OF2). Some conventional farmers agreed with organic farmers that conventionally produced crops sometimes use high levels of herbicides and pesticides typically claiming: "Farmers only use the minimum amount of pesticides necessary-more would have a detrimental effect on the crop" (CF17). Some writers question the use of herbicides; for example, [65] challenged small conventional Costa Rican coffee farmers' perceived need for herbicide use.

\subsection{UK and EU Agricultural Policy}

Both groups of respondents were asked a range of linked questions relating to government policy. These concerned first, how UK and EU agricultural policy related to damage to the UK farmed environment since World War Two; and second, if they thought UK and EU policy will go some way to "restore" farmland environments 
to pre-intensification levels.

Five key findings emerged. First, many more organic than conventional interviewees understood that in the past, government policy had caused considerable damage to farmed environments, typically stating: "There's obviously been a damaging effect such as the amount of hedgerows removed in the name of so-called good farming” (OF2). Secondly, almost five times as many conventional as organic farmers said that the damage to farmed environments has been minimal, typically commenting: "I suppose some places where the water comes from you have to be a bit careful with nitrates and things [herbicides and pesticides], but on the whole I don't think it's a problem" (CF10). "No I don't think it has-you could get government grants for grubbing out hedges ...” (CF4). It is noteworthy that some organic farmers see past damage to farmed environments, epitomised by grubbing out hedges, as the government's responsibility; thus contrasting with some conventional respondents who commented that farmers could get grants for hedge removal, yet continued to understand it wasn't the government's fault.

Thirdly, a great many more conventional than organic farmers think policy changes would go some way to "restore" farmland environments to pre-intensification levels, illustrated by quotes such as: "Yes, they are under pressure by the public to do so" (CF25). "Grants will help to put hedges and ponds back in” (CF17). Fourthly, more organic than conventional respondents believed that governments will only go some way to restore farmland environments, typical responses included: "We got paid for both, removing hedges and putting them back in again" (OF3). Fifthly, over twice as many organic than conventional respondents understood that governments will not restore any farmland environments, typically commenting: "I have no faith in what politicians say - they never seem to do what they say they will do" (OF16). Generally, conventional farmers seemed to have more faith in the government's willingness to rectify past environmental damage to farmed environments than organic respondents.

This sub-section has demonstrated some significant differences, but also a degree of overlap, in the understandings of UK and EU agricultural policy between the two survey populations. For example, conventional farmers' believe that only minimal environmental damage has been caused by government policy, contrasting with organic respondents' understanding that there has been a great deal of damage to farmed environments as embodied by filling in ponds, hedgerow removal and herbicide usage.

\section{Productive Farm Parts}

This section uses on-farm "intensive” qualitative/interpretive interviews to ascertain if the respondents' attitudes, understandings and behaviours in relation to their productive farm parts support the findings revealed by the earlier "extensive" telephone interviews.

All conventional farmers said that some parts of their farm were more productive than others, relating productivity to practical issues such as their farming practices, relative field heights, "natural" differences in soil fertility and, in some instances, the quantity and type of fertilisers used in relation to time scales of particular applications. The importance of having large fertile fields for arable cropping was emphasized by CF1 who manages the largest farm in the survey. This had been achieved through first, hedge removal and, secondly, by herbicide and fertiliser applications. Another interviewee CF2 seemed equally knowledgeable about the complex topography of his land and discussed in detail its location in two river valley flood plains and the resulting problems of flooding, access, soil types and subsequent plant species:

“... some meadows are in the Countryside Stewardship Scheme and they want it made into hay late in the season so that flowers, we call them weeds, when they are ready to seed, keep the weed-bank or flower seeds up ... we go on with a reasonably cheap chemical ...” CF2.

These comments show the respondent's real feelings towards the Countryside Stewardship Scheme (CSS) and the "wild flowers", resulting from their recommended management practices, which he controls by means of herbicides. Until the launch of Environmental Stewardship, Countryside Stewardship was the government's main scheme for countryside management.

OF4 did not believe she has any particularly productive areas on her farm and seemed to associate productivity with arable crop production, although her sheep farmer brother CF4, who is a neighbouring farmer on an almost identical farming landscape, identified differences in field productivity and catalogued a range of variables such as relative field heights, soil thickness and fertility. With a remarkably different understanding of soil "quality", one mixed organic farmer seemed proud of his soil's lack of productivity as, in parts, it produced an 
abundance of wild flowers on his complex nutrient poor chalk soils:

“... obviously unfertilised and un-manured in living memory. We also have steep chalk grassland which is extremely unproductive and we have grassland on other chalk banks and which is relatively unproductive" OF1.

This respondent understood the important relationship between soil types and the resulting variety of wild plant species and arable crops and, significantly, focused on the lack of soil productivity on some parts of his holding. OF2 talked about field aspect, crop rotation, field drainage and seasonal differences in soil fertility. Although soil fertility was not measured, respondents understood the considerable variability within and between fields on farms of different sizes, types and altitudes. CF1 and CF4 equated soil fertility with technical issues such as field heights, combined with high levels of fertilisers and the resulting crop income, contrasting significantly with discussions of "natural" differences in soil fertility OF2 and pride in lack of fertiliser use OF1. Such comments demonstrated farmers' diversity in understandings of the plant species resulting from differences in field productivity i.e. CF2's understanding of wild flowers as weeds contrasting significantly with the chalk-loving wild flowers of OF1. Herbicides have been a significant factor in the declines of many once common arable flowers in the UK [66] and, although organic farming systems generally have a larger floral and faunal biodiversity than conventional systems [67], there has been an associated erosion of heterogeneity as a consequence of agricultural intensification [68].

The farmers' understandings and behaviours revealed in this section generally reflect and support the environmental findings of the previous section towards agricultural weeds, pesticide and herbicide usage, biodiversity and agricultural sustainability. For example, as revealed in the technocentric understandings of CF1 and CF4, contrasting significantly with the ecocentric understandings of OF1 and OF2 when questioned about their soils' productivity.

\section{Conclusions}

Using a behavioural approach, this paper examined and attempted to explain how the understandings and behaviours of farmers, in central-southern England, relate to agricultural weeds, herbicide and pesticide usage, biodiversity and other selected environmental influences on agricultural sustainability. It would be unwise, however, to understand those farmers, commonly known as "organic" and "conventional", as exclusively "organic" or "conventional"; for example, [23] described organic farming as a family of styles that share some basic assumptions, rather than a single set of farming practices. Importantly, [38] acknowledged the difficulties of differentiating between organic and conventional farmers' motivational viewpoints. Considerable differences in understandings and behaviours were revealed between the two survey populations in relation to three core interrelated agri-environment themes; for example, many more organic than conventional farmers in the survey sample understood that organic farming systems are environmentally sustainable forms of agriculture. Organic farmers tended to cite their lack of pesticides and herbicides usage as core reasons for their sustainability. Although there remains a pressing need for longitudinal studies to address our knowledge of organic farming before a full appraisal of its role in biodiversity and agricultural sustainability can be made [18], other studies showed that organic management does increase plant richness in field centres of some Irish dairy farms [69]. Research by [35] suggests that the objectives of weed control and conservation may not be mutually exclusive because seed return was most reduced where ground remained uncultivated through the winter, yet this also provides the best foraging opportunities for surface feeding seed predators.

Conventional respondents mainly cited land and financial reasons for their non-adoption of organic farming with a number demonstrating strong technocentric attitudes. In contrast, the most often quoted reason given for adoption of organic farming systems by organic respondents were environmental reasons. This included their abhorrence of pesticide and herbicide usage sometimes experienced while working on conventional farms earlier in their career, thereby indicating their ecocentric attitudes and understandings. A remarkably high 92 per cent of organic farmers were critical of conventional farmers' using herbicides and pesticides which they understood are detrimental to water and soil quality. In contrast, most conventional respondents said that they used as few chemicals as practical to minimise environmental damage to soil and water while maintaining adequate crop levels. Conventional farmers' fields were usually kept weed-free through herbicide usage contrasting with organic farmers' having less concern about removing weeds-with their associated invertebrates and weed seedswhich contribute significantly towards biodiversity as an important environmental influence on agricultural sustainability. A recent study by [19] shows that herbicides contribute significantly to agricultural intensification 
and some negatively impact non-target organisms; however, the presence of weeds in a crop does not automatically result in damage or yield loss [33].

Many more organic than conventional farmers understood that government policy has caused considerable damage to farmed environments, principally through large-scale hedge removal, pond infilling and weed removal through herbicide usage. This contrasted with almost five times as many conventional as organic farmers who understood that damage to farmland has been minimal. A great many more conventional than organic farmers thought that policy changes would go some way to "restore" farmed environments to pre-intensification levels contrasting with more organic than conventional respondents understanding that governments will only partially restore those habitats. Reference [70] supported that viewpoint by suggesting that the government has limited growth in the British organic sector by constructing three separate story-lines: first, organics as "niche market demand"; secondly, organics as "an environmental public good" and thirdly, organics as "consumer choice" but not healthier.

All conventional farmers understood that some parts of their farm were more productive than others often relating productivity to their farming practices. For example, CF1 achieved large fertile fields for arable cropping through hedge removal and herbicide and fertiliser applications. Interestingly, [71] found that increases in such fertiliser applications had little influence on weed seed-bank composition. CF2 seemed equally knowledgeable about the complex topography of his land and commented on the wild flowers-he called weeds-resulting from his farming practices. This behaviour contrasted significantly with OF1 who understood the important relationship between soil types and the variety of wild plant species resulting from his nutrient poor unfertilised soil. The understandings of farmers towards the plant species resulting from differences in field productivity were epitomised by CF2's understanding of wild flowers as weeds requiring herbicide treatment, contrasting significantly from OF1's perception of such plants as wild flowers. As [72] suggests, depending on a farmer's environmental understandings, wild flowers in the wrong fields are often perceived as weeds.

This study found that farmers' understandings and behaviours towards agricultural weeds and herbicide usage varied greatly. Understandings are highly complex as they require insight confirmation by many similar cases to be generalised into a useful and coherent understanding [57]. Many "conventional” farmers understood weeds as primarily interfering with the desired use of a specific field in a particular season. Importantly, excessive weed removal from "conventional" farming systems causes biodiversity reduction with an associated loss of agricultural sustainability. In contrast, many "organic' farmers" perceived some weeds species as desirable wild flowers, although they also understand that too many weeds in an undesirable location may reduce crop production. Generally, such understandings support the study proposition that "organic" farmers already attuned to environmental ideas are more likely to have more favourable understandings and behaviours towards agricultural weeds as an important part of environmentally sustainable agricultural farming systems than "conventional" farmers.

\section{Acknowledgements}

I wish to record my thanks to the twenty five organic farmers and twenty five conventional farmers who took part in the "extensive" telephone interviews. I am particularly grateful for the dedication, interest and insights provided by the five geographically linked pairs of organic and conventional farmers who generously gave of their time and shared their knowledge in the "intensive" qualitative/interpretive interviews.

\section{References}

[1] European Weed Research Society (2011) A definition of Weeds. Weed Research, 51, 1.

[2] Schonbeck, M. (2011) Principles of Sustainable Weed Management in Organic Cropping Systems. 3rd Edition, Workshop for Farmers and Agricultural Professionals on Sustainable Weed Management, Clemson University, USA.

[3] Bengtsson, J., Ahnstrom, J. and Weibull, A.C. (2005) The Effects of Organic Agriculture on Biodiversity and Abundance: A Meta-Analysis. Journal of Applied Ecology, 42, 261-269. http://dx.doi.org/10.1111/j.1365-2664.2005.01005.x

[4] Franke, A.C., Lotz, L.A.P., vander Burg, W.J. and van Overbeek, L. (2009) The Role of Arable Weed Seeds for Agroecosystem Functioning. Weed Research, 49, 131-141. http://dx.doi.org/10.1111/j.1365-3180.2009.00692.x

[5] Pocock, M.J.O., Evans, D.M. and Memmott, J. (2012) The Robustness and Restoration of a Network of Ecological Networks. Science, 335, 973-977. http://dx.doi.org/10.1126/science.1214915 
[6] World Commission on Environment and Development (1987) Our Common Future. Oxford University Press, Oxford.

[7] Farshad, A. and Zinck, J.A. (2003) Seeking Agricultural Sustainability. Agriculture, Ecosystems and Environment, 47, 1-12. http://dx.doi.org/10.1016/0167-8809(93)90132-9

[8] Redclift, M. (1987) Sustainable Development: Exploring the Contradictions. Methuen, London. http://dx.doi.org/10.4324/9780203408889

[9] Redclift, M. (1992) The Meaning of Sustainable Development. Geoforum, 23, 395-403. http://dx.doi.org/10.1016/0016-7185(92)90050-E

[10] O’Riordan, T. (1997) Ecotaxation and the Sustainability Transition. In: O’Riordan, T., Ed., Ecotaxation, Earthscan, London, 7-20.

[11] Spedding, C. (1998) Sustainable Agriculture. The International Journal of Human Rights, 2, 29-39. http://dx.doi.org/10.1080/13642989808406727

[12] Edward-Jones, G. and Howels, O. (2001) The Origin and Hazard of Inputs to Crop Protection in Organic Farming Systems: Are They Sustainable? Agricultural Systems, 67, 31-47. http://dx.doi.org/10.1016/S0308-521X(00)00045-7

[13] Fairweather, J.R. and Campbell, H.R. (2003) Environmental Beliefs and Farm Practices of New Zealand Farmers: Contrasting Pathways to Sustainability. Agriculture and Human Values, 20, 287-300. http://dx.doi.org/10.1023/A:1026148613240

[14] Ilbery, B. and Maye, D. (2005) Food Supply Chains and Sustainability: Evidence from Specialist Food Producers in the Scottish/English Borders. Land Use Policy, 22, 331-344. http://dx.doi.org/10.1016/j.landusepol.2004.06.002

[15] Maxey, L. (2007) From “Alternative” to “Sustainable” Food. In: Maye, D., Holloway, D.L. and Kneafsey, M., Eds., Alternative Food Geographies: Concepts and Debates, Elsevier, Oxford, 55-75.

[16] Shoard, M. (1980) The Theft of the Countryside. Temple-Smith, London.

[17] Pugliese, P. (2001) Organic Farming and Sustainable Rural Development: A Multifaceted and Promising Convergence. Sociologia Ruralis, 41, 112-130. http://dx.doi.org/10.1111/1467-9523.00172

[18] Hole, D.G., Perkins, A.J., Wilson, J.D., Alexander, I.H., Grice, P.V. and Evans, A.D. (2005) Does Organic Farming Benefit Biodiversity? Biological Conservation, 122, 113-130. http://dx.doi.org/10.1016/j.biocon.2004.07.018

[19] Storkey, J., Meyer, S., Still, K.S. and Leuschner, C. (2012) The Impact of Agricultural Intensification and Land-Use on the European Arable Flora. Proceedings of the Royal Society B: Biological Sciences, 279, 1421-1429. http://dx.doi.org/10.1098/rspb.2011.1686

[20] Codex Alimentarius Commission (1999) What Is Organic Agriculture? FAO/WHO Codex Alimentarius Commission.

[21] International Federation of Organic Agriculture Movements (2008) Press Release 22nd January 2010.

[22] Darnhofer, I., Schneeberger, W. and Freyer, B. (2005) Converting or Not Converting to Organic Farming in Austria: Farmer Types and Their Rationale. Agriculture and Human Values, 22, 39-52. http://dx.doi.org/10.1007/s10460-004-7229-9

[23] Reed, M. (2010) Rebels for the Soil: The Rise of the Global Organic Food and Farming Movement. Earthscan, London.

[24] Fuller, R.J. (1997) Responses of Birds to Organic Arable Farming: Mechanisms and Evidence. 1997 Brighton Crop Protection Conference-Weeds Proceedings, Brighton, 17-20 November 1997, British Crop Protection Council, Farnham, 897-906.

[25] Lampkin, N. (2002) Organic Farming. Old Pond, Ipswich.

[26] Guthman, J. (2004) The Trouble with “Organic Lite” in California: A Rejoinder to the “Conventionalisation” Debate. Sociologia Ruralis, 44, 301-316. http://dx.doi.org/10.1111/j.1467-9523.2004.00277.x

[27] Duram, L.A. (2000) Agents’ Perceptions of Structure: How Illinois Organic Farmers View Political, Economic, Social and Ecological Factors. Agriculture and Human Values, 17, 35-48. http://dx.doi.org/10.1023/A:1007632810301

[28] Kings, D. and Ilbery, B. (2012) Organic and Conventional Farmers’ Attitudes towards Agricultural Sustainability. In: Konvalina, P., Ed., Organic Farming and Food Production, InTech, Open Access Publishers, 121-144.

[29] Morgan, K. and Murdoch, J. (2000) Organic vs Conventional Agriculture: Knowledge, Power and Innovation in the Food Chain. Geoforum, 31, 159-173. http://dx.doi.org/10.1016/S0016-7185(99)00029-9

[30] Bond, W. and Grundy, A.C. (2001) Non-Chemical Weed Management in Organic Farming Systems. Weed Research, 41, 383-405. http://dx.doi.org/10.1046/j.1365-3180.2001.00246.x

[31] Walz, E. (1999) Third Biennial National Organic Farmers’ Survey: Organic Farming Research Foundation. Santa Cruz, CA.

[32] Finney, D.M. and Creamer, N.G. (2006) Weed Management on Organic Farms. Centre for Environmental Farming 
Systems, North Carolina.

[33] Power, E.F., Kelly, D.L. and Stout, J.C. (2013) The Impacts of Traditional and Novel Herbicide Application Methods on Target Plants, Non-Target Plants and Production in Intensive Grasslands. Weed Research, 53, 131-139. http://dx.doi.org/10.1111/wre.12009

[34] Jose-Maria, L. and Sans, F.X. (2011) Weed Seedbanks in Arable Fields: Effects of Management Practices and Surrounding Landscape. Weed Research, 51, 631-640. http://dx.doi.org/10.1111/j.1365-3180.2011.00872.x

[35] Holland, J.M., Smith, B.M., Southway, S.E., Birkett, T.C. and Aebischer, N.J. (2008) The Effect of Crop, Cultivation and Seed Densities in Arable Crops during Winter. Weed Research, 48, 503-511. http://dx.doi.org/10.1111/j.1365-3180.2008.00663.x

[36] Albrecht, H. (2003) Suitability of Arable Weeds as Indicator Organisms to Evaluate Species Conservation Effects of Management in Agricultural Ecosystems. Agriculture, Ecosystems \& Environment, 98, 201-211. http://dx.doi.org/10.1016/S0167-8809(03)00081-1

[37] Buck, D., Getz, C. and Guthman, J. (1997) From Farm to Table: The Organic Vegetable Commodity Chain of Northern California. Sociologia Ruralis, 37, 3-20. http://dx.doi.org/10.1111/1467-9523.00033

[38] Lockie, S. and Halpin, D. (2005) The Conventionalisation Thesis Reconsidered: Structural and Idealogical Transformation of Australian Organic Agriculture. Sociologia Ruralis, 45, 284-307.

[39] Best, H. (2008) Organic Agriculture and the Conventionalization Hypothesis: A Case Study from West Germany. Agriculture and Human Values, 25, 95-106. http://dx.doi.org/10.1007/s10460-007-9073-1

[40] Rosin, C. and Campbell, H. (2009) Beyond Bifurcation: Examining the Conventions of Organic Agriculture in New Zealand. Journal of Rural Studies, 25, 35-47. http://dx.doi.org/10.1016/j.jrurstud.2008.05.002

[41] Campbell, H., Rosin, C., Norton, S., Carey, P., Benge, J. and Moller, H. (2010) Examining the Mythologies of Organics: Moving beyond the Organic/Conventional Binary? In: Lawrence, G., Lyons, K. and Wallington, T., Eds., Food Security and Sustainability, Earthscan, London, 238-251.

[42] Coombes, B. and Campbell, H. (1998) Dependent Reproduction of Alternative Modes of Agriculture: Organic Farming in New Zealand. Sociologia Ruralis, 38, 127-145. http://dx.doi.org/10.1111/1467-9523.00068

[43] Hall, A. and Mogyorody, V. (2001) Organic Farmers in Ontario: An Examination of the Conventionalization Argument. Sociologia Ruralis, 41, 399-422. http://dx.doi.org/10.1111/1467-9523.00191

[44] Davis, A.S., Hall, J.C., Jasieniuk, M., Locke, M.A., Luschei, E.C., Mortensen, D.A., Riechers, D.E., Smith, R.G., Sterling, T.M. and Westwood, J.H. (2009) Weed Science Research and Funding: A Call to Action. Weed Science, 57, 442-448. http://dx.doi.org/10.1614/WS-09-020.1

[45] Barberi, P. (2002) Weed Management in Organic Agriculture: Are We Addressing the Right Issues? Weed Research, 42, 177-193. http://dx.doi.org/10.1046/j.1365-3180.2002.00277.x

[46] Burton, R.J.F. (2004) Reconceptualising the "Behavioural” Approach in Agricultural Studies: A Socio-Psychological Perspective. Journal of Rural Studies, 20, 359-371. http://dx.doi.org/10.1016/j.jrurstud.2003.12.001

[47] Wilson, G.A. (1997) Factors Influencing Farmer Participation in the Environmentally Sensitive Areas Scheme. Journal of Environmental Management, 50, 67-93. http://dx.doi.org/10.1006/jema.1996.0095

[48] Cloke, P., Philo, C. and Sadler, D. (1991) Approaching Human Geography: An Introduction to Contemporary Theoretical Debates. Paul Chapman, London.

[49] Brotherton, I. (1990) Initial Participation in UK Set-Aside and ESA Schemes. Planning Outlook, 33, 46-61. http://dx.doi.org/10.1080/00320719008711865

[50] Morris, C. and Potter, C. (1995) Recruiting the New Conservationists: Farmers’ Adoption of Agri-Environmental Schemes in the UK. Journal of Rural Studies, 11, 51-63. http://dx.doi.org/10.1016/0743-0167(94)00037-A

[51] Wilson, G.A. (1996) Farmer Environmental Attitudes and ESA Participation. Geoforum, 27, 115-131. http://dx.doi.org/10.1016/0016-7185(96)00010-3

[52] Beedell, J.D.C. and Rehman, T. (1999) Explaining Farmers' Conservation Behaviour: Why Do Farmers Behave the Way They Do? Journal of Environmental Management, 57, 165-176. http://dx.doi.org/10.1006/jema.1999.0296

[53] Beedell, J.D.C. and Rehman, T. (2000) Using Social-Psychology Models to Understand Farmers' Conservation Behaviour. Journal of Rural Studies, 16, 117-127. http://dx.doi.org/10.1016/S0743-0167(99)00043-1

[54] Kings, D. and Ilbery, B. (2010) The Environmental Belief Systems of Organic and Conventional Farmers: Evidence from Central-Southern England. Journal of Rural Studies, 26, 437-448. http://dx.doi.org/10.1016/j.jrurstud.2010.05.003

[55] Kings, D. and Ilbery, B. (2011) Farmers’ Attitudes towards Organic and Conventional Agriculture: A Behavioural Perspective. In: Reed, M., Ed., Organic Food and Agriculture: New Trends and Developments in the Social Sciences, 
InTech, Open Access Publishers, 145-168.

[56] Brookfield, H.C. (1969) On the Environment. In: Board, C., Chorley, R.J., Haggett, P. and Stoddart, D.R., Eds., Progress in Geography, Edward Arnold, London, 51-80.

[57] Ip, Y.K. (2003) Knowing Is Not the Same as Understanding: What Is Understanding? Centre for Development of Teaching and Learning, National University of Singapore, Singapore.

[58] Ilbery, B., Holloway, L. and Arber, R. (1999) The Geography of Organic Farming in England and Wales in the 1990s. Tijdschrift voor Economische en Sociale Geografie, 90, 285-295. http://dx.doi.org/10.1111/1467-9663.00070

[59] Ilbery, B. and Maye, D. (2011) Clustering and the Spatial Distribution of Organic Farming in England and Wales. Area, 43, 31-41.

[60] Ilbery, B. and Maye, D. (2010) Agricultural Restructuring and Changing Food Networks in the UK. In: Coe, A. and Jones, A., Eds., The Economic Geography of the UK, Sage, London, 166-180. http://dx.doi.org/10.4135/9781446269374.n12

[61] Pullen, D.W.M. and Cowell, P.A. (1997) An Evaluation of the Performance of Mechanical Weeding Mechanisms for Use in High Speed Inter-Row Weeding of Arable Crops. Journal of Agricultural Engineering Research, 67, 27-34. http://dx.doi.org/10.1006/jaer.1997.0148

[62] Leibman, M. and Davis, A.S. (1999) Integration of Soil, Crop and Weed Management in Low-External-Input Farming Systems. Department of Agronomy, Iowa State University, Ames, 27-47.

[63] Padel, S. (2001) Conversion to Organic Farming: A Typical Example of the Diffusion of an Innovation? Sociologia Ruralis, 41, 40-61. http://dx.doi.org/10.1111/1467-9523.00169

[64] O’Riordan, T. (1981) Environmentalism. 2nd Edition, Pion, London.

[65] Bellamy, A.S. (2011) Weed Control Practices on Costa Rican Coffee Farms: Is Herbicide Use Necessary for SmallScale Producers? Agriculture and Human Values, 28, 167-177. http://dx.doi.org/10.1007/s10460-010-9261-2

[66] Cooke, A.S. and Burn, A.J. (1995) The Environmental Impacts of Herbicides Used in Intensive Farming Systems. In: Brighton Crop Protection Conference: Weeds, British Crop Protection Council, Farnham, 603-612.

[67] Gomiero, T., Pimental, D. and Paoletti, M.G. (2011) Environmental Impact of Different Agricultural Management Practices: Conventional vs Organic Agriculture. Critical Reviews in Plant Sciences, 30, 95-124. http://dx.doi.org/10.1080/07352689.2011.554355

[68] Benton, T.G., Vickery, A.J. and Wilson, J.D. (2003) Farmland Biodiversity: Is Habitat Heterogeneity the Key? Trends in Ecology and Evolution, 18, 182-188. http://dx.doi.org/10.1016/S0169-5347(03)00011-9

[69] Power, E.F., Kelly, D.L. and Stout J.C. (2012) Organic Farming and Landscape Structure: Effects on Insect-Pollinated Plant Diversity in Intensively Managed Grasslands. PLoS ONE, 7, Article ID: e38073. http://dx.doi.org/10.1371/journal.pone.0038073

[70] Tomlinson, I. (2008) Re-Thinking the Transformation of Organics: The Role of the UK Government in Shaping British Organic Food and Farming. Sociologia Ruralis, 48, 133-151. http://dx.doi.org/10.1111/j.1467-9523.2008.00457.x

[71] DeCauwer, B., van den Berge, K., Cougnon, M., Bulcke, R. and Reheul, D. (2010) Weed Seedbank Responses to 12 Years of Applications of Composts, Animal Slurries or Mineral Fertilisers. Weed Research, 50, 425-435. http://dx.doi.org/10.1111/j.1365-3180.2010.00796.x

[72] McHenry, H. (1997) Wild Flowers in the Wrong Fields Are Weeds! Examining Farmers' Constructions of Conservation. Environment and Planning A, 29, 1039-1053. 
Scientific Research Publishing (SCIRP) is one of the largest Open Access journal publishers. It is currently publishing more than 200 open access, online, peer-reviewed journals covering a wide range of academic disciplines. SCIRP serves the worldwide academic communities and contributes to the progress and application of science with its publication.

Other selected journals from SCIRP are listed as below. Submit your manuscript to us via either submit@scirp.org or Online Submission Portal.
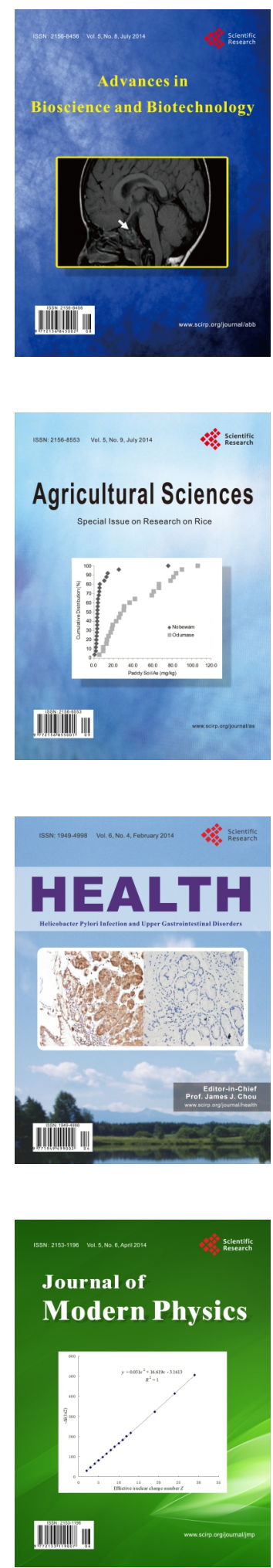
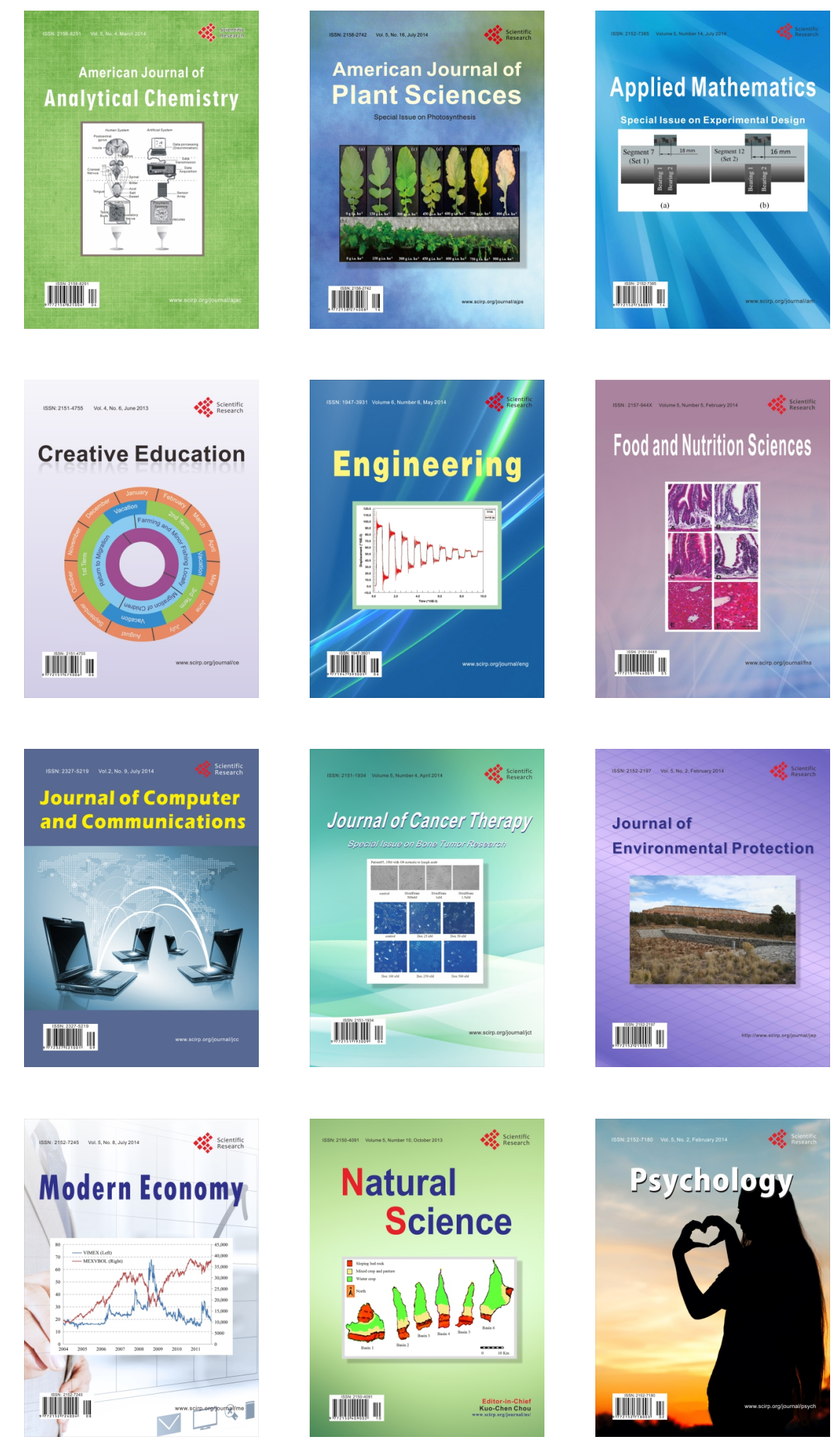